\title{
Issues in Freedom of Religion and the Relationship with Thailand's Constitution
}

\author{
Mutsalim Khareng ${ }^{1^{*}}$ \\ Jaffary Awang ${ }^{1}$ \\ Rohanee Machae ${ }^{2}$ \\ Zaizul Ab. Rahman ${ }^{1}$ \\ Khaidzir Ismail ${ }^{3}$ \\ ${ }^{1}$ Department of Theology and Philosophy, National University of Malaysia \\ 2 Department of Shariah, National University of Malaysia \\ ${ }^{3}$ Department of Psychology and Human Development Studies \\ *Corresponding Author Email: habba_yabnee@hotmail.com
}

\section{Doi:10.5901/mjss.2016.v7n4p}

\section{Abstract}

One of the elements in the idea of independence is the religious freedom for an individual to choose their own religion and practice it without any force or distraction from anyone. Thailand is known as a democracy country that promotes the freedom of rights to its citizens in all aspects of life including the rights of religious freedom. However, there are still doubts occurred between the Muslim and Buddhist in their interaction. This is because; there are rules and regulations that seem to limit the freedom of religion. Therefore, this study is using the analysis of the literatures produced related to the religious freedom phenomenon in the Southern Thai. Based on the study, the ruling factor is the main cause for the crisis to happen between the believers in the Southern Thai. The implementation of certain acts must be suitable with the situation and condition of a certain place as if it is not suitable, the citizens will react negatively towards the party who implemented the acts. Hence, it is important for the Southern Thais, who have different customs, languages, religions, social classes and other differences to have the specific law or rules and regulations for them to create the peaceful life for the society.

Keywords: freedom, the right of religious freedom, interaction, specific law.

\section{Introduction}

Human right is the inspiration for every individual to meet the happiness in their life. There have been countless of debates relating to the human rights since the early of human existence and civilization. In the international law, the Universal Declaration of Human Right has stated a variety of rights for human to live. Apart from the rights are freedom, justice, fighting for justice, fighting for the truth, minority right, an organized economy and development, copyright, social peace, family, women right, education, freedom to be confident, freedom of expressions, religious freedom and others.

The freedom of religion right has been stated in the $18^{\text {th }}$ item of the Declaration of Human Right that protects the people in the freedom of thinking, freedom of religion and belief, and there is no one can discriminate them based on the religious matters. There are a lot of alarming debates regarding the freedom of religion in the multiracial society among the academicians, especially in Thailand. The difference in religion has caused the different behaviour among the society. In that case, the debates on the freedom of religion should be conducted sincerely based on the limits, rules and regulations, conditions and implementation to make sure that the peaceful and calmness of the society can be retained.

\section{Research Background and Problem Statement}

Thailand is a democracy country that is ruled by the Siamese, with the majority of the citizens is Buddhists who believe in Theravada. Therefore, the status of Buddhists is higher than other citizens such as Muslims, Christians, Hindus and Sikhs. This marked an important role for the ruler to be fair in handling the rights of the citizens who came from various different religions. In a multiracial society context as in Thailand, the implementation of a policy was a very unique and hard effort. The ruler has to consider various aspects among various believers. This is so, as one policy might benefit 
certain races only while the other races did not get any benefit from that. As a result, this will lead to a tragedy that can cause destruction.

The community of Yala, Patani and Narathiwat in the Southern of Thailand are majoritily Muslims, who hold strongly to their religion and practice Malay cultures which are different from other majority citizens in Thailand. Even though they have different cultures and religious practices, physically they have changed from the image of the Malay Patani Muslims to the Thai Malays, as well as believing that they are the Thais and Thai in origin (Faiz, A. 2009: 2-3). It might be seen that the Malay Patani Muslims are the majority citizens of Southern of Thailand, but the truth is they have been treated as the minority in their own land because of the politics and ruling style that caused their life changed that way.

The continuation of conflict in the Southern of Thailand is basically formed by the differences in religions and races. These differences are serious as they are hard to be overcome (Wan Kadir C. M. 2002: 35-36). It is a very unique yet hard process of implementation of a policy in a community that possesses different religions. Thus, any act of abusing the policy can lead to the misunderstanding or in the worst case; it can cause conflicts between races. In reaction to that, this writing will thoroughly explain certain policies that have been implemented by the government towards the Muslim minority in the Southern of Thailand.

Among the policies are the cultural assimilation policy of Field Marshall Phibun Songkram (1938-1944) leadership, the national integration politics under Pridi Phanomyong (1945-1946) leadership and the compulsory regulations which all traditional Islamic schools (pondok) must be registered under the Ministry of Education Department during Field Marshall Sarit Thanarat (1961) leadership, used in Southern of Thailand that the majority are Muslims. There are a number of researchers who are interested to examine in depth because it appears most of the academic social and politics local as Dassaey, P. (1984), Jidmoud, S. (1988), Warner, K. (1998), Wan Kadir, C. (1998), Ahmad, O.C. (1998), Achwanichakun, K. (2009), Vachanasara, K. (2009), Siangdang, H. (2009) Alisa, H. (2009) have mutually agreed that all the policies lead by the mentioned superiors have given a negative impact upon all Muslim Malays at the Southern of Thailand. Other than that, Pissuwan, S. (1984) and Paiterakunpong, P. (2005), also criticised the implementation of the policy by pointing out that the unfair ruling as the effort in assimilating and integrating all the citizens have caused the tense among the Buddhist and Muslims in the Southern of Thailand. Hence, this also made the superior race is dominating the inferior race and that affects Muslim Malays in the Southern of Thailand negatively. Even though the policies are meant to unite the believers (Muslims and Buddhists) by practicing one culture, but it had actually instilled the feeling of prejudice from the superior race to the inferior race. In addition, this had also caused the freedom of religion been violated especially among Muslims and that marked their fights towards the government. Thus, this research will examine how far the policies play their role in influencing the Muslims in the Southern of Thailand.

\section{Research Methodology}

In a research, methodology is very important in guiding the researchers on how the data is collected. The explanation on the used methodology will ease the researcher in running the research systematically and time saving. This research analyzes the works related to the policies implemented over the Southern of Thailand community produced by the academicians. Thus, this research uses content analysis method. It is a research method that focuses on the materials from the mass media such as newspapers, magazines, journals, books, old books, written reports and other materials. This method can be used in various knowledge aspects such as politics, social, management, education and other aspects. It is very suitable to be used in analyzing the current issues, certain phenomenon to add more knowledge regarding the problem solution and explain the social curiosity that is related to the conducted analysis. In addition, the historical facts are also seen on how political developments since then until now that the findings accurately and relevant with research topics.

\section{Discussion}

\subsection{Policies that Restrict Freedom of Religion in Southern Thailand}

As was stated earlier that most of the social and political academics local agreed that in the framework of policies government to the community of South Thailand, there appears to be some policies restrict freedom of religion, especially among Muslims in Southern Thailand. In the ruling policy, there are few bases which can be seen to limit the freedom of religion among the Muslims as in the policy of assimilation during the rule of Field Marshall Phibun Songkram in 19381944. He was the extreme nationalist ruler that made Thailand as developed as Japan, Germany and Italy. In his 
opinion, Thailand will not be developed if they still practice the different cultures among the citizens while living in the same country. He wanted to have Thailand as a racist country that practices only one culture with the Thai way of life for the Thais. This is called the Thai Rathaniyom. The implementation of Thai Rathaniyom has worried everyone especially Muslims Patani as this will instill the western culture and Buddhism that can threaten the identity of Muslims Patani as the minority in Thailand. In order to make Thai Rathaniyom a success, Thailand ruler has built spha wathana'tham (cultural hall) in 1940 (Suhaimi, C. H. 2007: 19-20).

The Thai Rathaniyom policy has been the starting point of the Thailand government in the Islamic matters. This is because, the prior Islamic laws have been diminished by Phibun, and that laws are replaced with the civil laws. Phibul has declared war to the effort of developing Islam. Buddhist idols have been placed in the schools, while the Muslim students have been forced to pray to the idols as the Buddhist students did. At the same time, Muslims Patani have been forced to change their Muslim names to Siam names, they also need to learn and speak in Siam language, without any business in Malay language is allowed in government offices, they cannot also learn al-Quran but they need to learn Buddhism, they need to wear pants, hat and the women are not allowed to wear hijab (Achwanichakun, K. Vachanasara, K. \& Siangdang, H. 2009: 4). By having this policy, most of the Patani Muslims have been tortured and killed as they did not want to follow the policy.

However, in 1945-1946, the government ruled by Pridi Phanomyong has saved the Patani Muslims by giving them the freedom in practicing Islamic rules (Warner, K. 1998: 48), as well as supporting the Islamic matters such as creating the Cularajmontri (Thailand highest religious board), the committee for Islamic matters, the Islamic educational institution and giving permission to learn the Islamic knowledge in Malay and Arabic. However, that freedom did not satisfy the Muslims as it portrays that the government has the ultimate power in determining the roles of the 'ulama' in all Islamic aspects and there is still effort in assimilating and mixing the Buddhism to Islam (Pissuwan, S. 1982: 10).

Other than that, it is impossible to forget the bitter experience of the Malays during the reign of the Field Marshall Phibun Songkram. According to Wan Kadir C.M. 1998, Malays have once again been the victims of the Thailand government when they failed to influence the education and Thai language towards the Malays. As a result, the government under the reign of Sarit Thanarat had begun a policy by changing the traditional Islamic school to a registered private Islamic school in 1961.

This policy is meant to build a strong foundation for the Thai language and education, especially to the three districts of the Southern Thailand. By referring to this new policy, all the traditional Islamic schools (pondok) have to use a curriculum that has been prepared by the government and Thai language should be the lingua franca in the education system. Besides, the Islamic subjects were allowed to be taught as long as they follow the rules and conditions prepared by the National Ministry of Education. In addition to that, any traditional Islamic school (pondok) that failed to obey the rules and conditions prepared by the National Ministry of Education will be labelled as non-registered institution and will eventually demolished by them. That policy had caused a big number of the traditional Islamic schools (pondok) had been changed to the registered Islamic schools and made the total number of the registered Islamic schools had reached to 348 in 1984. Nevertheless, only 202 schools from the big number were fully functioning. This demolishing policy had been regarded by the scholars as an achievement of the Thai integration policy in the three districts of the Southern Thailand. It had not just shut down all the cultures installation by the traditional Islamic schools (pondok) in preventing the invasion of the external cultures but, it had also stopped the traditional Islamic educational system which had been wellknown with the religious knowledge.

At the same time, Sarit's reign had introduced a project to change the imbalance faces among the Muslims and Buddhist in the Southern of Thailand. That project was known as Nikom Sang Toneang and it provided 7.2-10 acres of land to every Buddhist family who migrated from other districts to the three districts of the Southern of Thailand. As a result, there were about 100,000 of citizens who were living the districts of the Southern of Thailand in 1961. Based on the Muslim separatist's opinion, the Nikom policy was a government scheme that indirectly decreased the amount of Malays and eventually made the area of Southern of Thailand as the area of the Buddhist (Wan Kadir C. M. 2002: 17).

Thus, it marked the continuation of the bitter experience of the Malay Pattanis. In the early of 1970, the Ministry of Home Affairs had planned an Islamic Da'wah programme by distributing the Quranic texts with errors in writing to the Muslim Malays in the Southern of Thailand. After that, in 1980, the Ministry of Education had spread a religious text that contained the picture of Prophet Muhammad P.B.U.H to the Muslim children in the Southern of Thailand. Even though those acts had always been protected by the respective officers as the unintentional acts, they were actually planned as the evil effort to betray the Muslim Malays especially the citizens of the Southern of Thailand.

Based on the above statement, it can be seen that from time to time, Thailand government still cannot be considered as the Plural Society. This can be proved by the act of Thailand rulers who are trying to diminish the Malay Patani Muslim's identity by growing the love towards Siam. This effort is very obvious where they have organized some 
programs to make the Malay Patani Muslim to become the Siamese. Those programs are way too different from the Malay Patani Muslims' life (religion, language, custom and practice) such as the assimilation and integration of culture to diminish the Malay Patani Muslim identity.

In fact, in terms of religion, culture, language and custom, the Muslim Malays in the Southern of Thailand possess their own background which is different from the majority residences of Thailand, the Buddhists. This caused the effort by the government to implement a policy in avoiding the misunderstanding between the believers became harder.

The policies such as the cultural assimilation policy lead by Field Marshall Phibun Songkram (1938-1944), the national politics integration lead by Pridi Phanomyong (1945-1946) and the rules that make it compulsory for every traditional Islamic school to be registered under the Ministry of Education Department lead by Field Marshall Sarit Thanarat (1961). Even though the purpose is to unite all the believers and mould a civilised community, the policies had indirectly affected the Patani Muslim Malays negatively because of the cultural assimilation policy, the national integration and other policies had played an important role in demolishing the Malay identity which had been the heritage of the Patani Muslim Malays' ancestors, by instilling the love towards the Siamese and changed the Malays into Siamese. Therefore, most of the Patani Malays felt that such act had made them been discriminated and forced to obey the government that they do not like. That also caused the various rebellious acts towards the reign of Thailand.

Besides, it should be understood that, in a multiracial, multireligious and various skin colours community, the conflicts that can lead to disagreement and destruction are easier to occur. Thus, it is a very hard and unique effort in moulding a stable community. The misuse of certain policies can be the cause of the conflict among the races. In order to avoid any conflict, it is the responsibility of every religion and citizen, especially the rulers to be motivated and honest in playing their role to strengthen the relationship among the citizens as well as building a harmonious community. At the same time, all believers should realize that all religions have their own good values such as the awareness of living in a community, tolerance, understanding, respect, patience, peace and other positive values. These kinds of values should be prioritised and spread to all citizens so that they can be understood as well as increasing the understanding.

\subsection{Among the Controversial Tragedies Faced by Muslims in the Southern of Thailand.}

Changing the Muslim Malays into Siamese programs with the cultural assimilation policy of Field Marshall Phibun Songkram (1938-1944) leadership, the national integration politics under Pridi Phanomyong (1945-1946) leadership and the compulsory regulations which all traditional Islamic schools (pondok) must register under the Department of Ministry of Education during Field Marshall Sarit Thanarat (1961) leadership, found to inhibit the right of Muslim Malays at the Southern Thailand, especially in terms of religious practice. Thus, emerging resistance reaction among Muslim Malays against government and it is continuous and lasting until now.

According to Rangsiyokret, S (1967), Other than that, the oppression of right can also be seen in the government offices, where the civil servants are very rude and bias in treating the Muslims compared to the Buddhist where they are being treated politely. Thus, the interaction between the civil servants and the Muslims of Southern Thailand is actually portraying the relationship between the ruler and the one who is being ruled, not between the party who offer a service to the citizens, like what have been practiced in other democratic countries, that known as public servant (Rangsiyokret, S. 1967: 55). This is due to the attitude of the civil servants who ignored Islam and its culture, by insulting the Muslims by calling them stupid, misguided and other negative labels (Supab, C. 1974: 79).

The oppression of rights of the Muslim Malays in the Southern of Thailand does not only come from the practices of religions and customs, but it also involved their daily lives' rights. This is supported by Jidmoud, S. (1988), where he highlighted that by looking at the human rights in a conflicting country especially the Southern of Thailand, it was obviously seen that the rights of Muslim Malays had been oppressed. The oppression did not only involve their customs and religious practices, but it also involve their daily lives' rights such as they got bad treatment at the government offices and they were humiliated and accused with bad words. Moreover, some of the government officers did not give full attention to the Muslim customers. Hence, all those incidents made them become the victims and their rights did not completely acknowledged (Jidmoud, S. 1988: 157).

According to Duangpattra, S. (1977), the community of Southern Thai is the abandoned community as they need to be independent without any help from the government. In the worst condition, the civil servants or the government workers themselves are trying to destroy the good relationship that should be experienced by the believers, such as the civil servants are being injustice towards Muslims, they ignored the problems faced by the Muslims as well as the context experienced by the Southern Thailand (Duangpattra, S. 1977: 259).

Consequently, it can be said that almost every controversial tragedy that happened in the Southern of Thailand was caused by the government officers as they also tried to make things worst. For instance, in $11^{\text {th }}$ December 1987, the 
right of practising the religion had been violated among Muslims of the Southern of Thailand. It started when a group of Muslims women in Yala Rajabhat University, through the president of Islamic Morale Encouragement Society wrote a permission letter to the university's administration regarding wearing the Muslims' attire (wearing hijab). However, in 14 December 1987, the vice president of students' activities department announced that the application to the Muslims' attire was rejected as it violated the discipline rules that had been set by the university. This was also rejected as the administration believed that the idea did not come from the students but that was actually from the mind of Patani's Freedom Fighters who made the students as their object in their fighting mission. After the announcement regarding the rejection of wearing the Muslims' attire had been published, majority of the students and university's committee felt disappointed on that. Thus, it leads to a major riot in Yala Mosque on $11^{\text {th }}-12^{\text {th }}$ February 1988. The riot proved that almost all levels of society were paying their attentions to the issue and there were also supports from the local ministers and a few government organizations such as Southern Border Provinces Administration Centre, Sheikhul Islam Office and Muslims Council of five districts of the Southern of Thailand. Hence, the riot had been settled successfully after the local minister Wan Muhammad Nor Mata announced that the Yala governer, Minister of Education and National Security had mutually agreed to be tolerant in the discipline of Muslim women attire.

The highlight of the controversy among the university students was again occurred on $22^{\text {nd }}$ February 1988 . This was caused by a group of the university lecturers did not allow the students to wear scarf (hijab) during the final semester examination. The second riot is the biggest riot as it was attended by 18,000 crowds and among them are the students, women in hijab, religious elites, civil servants, local ministers and the public that came from various places and that made the riot lasted until 9 days. In the end, the crisis of wearing hijab was settled in $2^{\text {nd }}$ March 1988 after the Ministry of Education and the university administration were willing to approve all the requests proposed by the students. This second riot attracted the attention of the public as it was the beginning of all the fighting missions in claiming the religion's rights among the Malay Patani Muslims. In addition, the movement also caused various perceptions among the academicians and they were debating on "Why only now they want to start wearing hijab?"

In 1988, there was a controversy made by the assistant governor of Narathiwat, Sriyaphan, S. where he criticized and humiliated the Islamic practices including the wearing of niqab among the Muslim women that had been a hot debate at that particular time. He said that "human has their own rights in life, but wearing niqab among the Muslim women is an act of force that violated the women's right. Muslim women do not have the right to choose what they wanted; instead they had been the objects to men, while the religion was forcing them too" (Jidmoud, S. 1988: 320). In reaction to his statements, the citizens of the Southern of Thailand were fighting on that and he had been asked to resign as the assistant governor of Narathiwat.

The issue of wearing niqab had again been a hot debate in 2011. In that year, a Muslim girl who studied at the secondary level in Sekolah Kerajaan Vad Nongcok (Bangkok) had applied to wear niqab during her school time, but it was rejected. After that, on $1^{\text {st }}$ December 2011, the committee of Sekolah Kebangsaan Vad Nongcok had officially announced that wearing niqab is not permitted in the school area whether among the students or the staff as it violated the school's rule, the ministry of education's rule and the school's cultural rule that had been set, even though the area involved is lived by the Muslim majority of $75 \%$ compared to the Buddhists which were only $20 \%$ of them (Mamau 2012). That result had caused Redha Ahmad Samadee (The President of Muslim Council for Peace), Yongyud Kedleca as the advisor and almost 200 students from various places held a demonstration in front of the Bangkok Parliament Centre on $10^{\text {th }}$ January 2012. They had appealed to the President, Yinglak Chinnawat to give explanation regarding that issue (Dailynews 10/01/2012).

However, presently wearing niqab is a normal issue in the Southern of Thailand. The rules of attire in Thailand had been expanded, but the issue of wearing niqab is still being debated especially in the context of Muslim minorities. The decision from the committee of Sekolah Menengah Vad Nongcok where they did not allow the Muslim women to wear niqab at the school area showed the injustice incident in the society. Even though the freedom of religion had always been the mission of the government as it is written in the Thailand's constitution, Section 37 on the freedom of embracing, practicing and spreading it, there are still some Buddhists who ignore the agreed rules and law. They also make their customs as their main laws compared to the constitutional laws that causes the occurrence of doubts in practicing the different religions, cultures and customs. However, recognition the right to freedom of religion until enshrined in Constitution of Thailand prove there is justice among governments at the one level.

\subsection{The Government Supports and Help in Dealing with the Issue of Freedom of Practising the Religion Among the Believers}

Although, infringement right of religious always happen, but freedom of religion still guaranteed by Constitution of 
Thailand in Thailand Constitutional Act Section 37 states that "the religious freedom is based on the right of privacy where humans have the right choose and embrace any religion that they agreed on. The religious freedom is the ultimate freedom with the meaning that the government does not have any rights to determine or plan the citizens' religious matters. At the same time, the practice of religion should be limited to the teaching that will not oppress the public harmony that could bring to chaos". While in Section 79 , "the government should protect and make sure that the safety of the foreign religion is guaranteed as well as supporting the understanding efforts between the believers" (Constitution of Thailand, Amendment 2007).

\subsubsection{Financial Assistance for the Development and Propagation of Religion in Thailand}

Constitution of Thailand (Amendment 2007) section 30 states that "every person has the legal equality and equal protection of the right to acquire, whether male or female" The explanation of the act, that is not allowed selective behalf of any group with whether the reason difference of race, language, gender, age, disability, status in society, religious beliefs, positions in education, and opinion on politics that not inconsistent with Constitution. By referring to that rule, the Constitution of Thailand did not announce any religion as the official religion in Thailand even though the majority of citizens are the Buddhists (Theravada). However, the status of Buddhism is higher compared to the other religions as its relation to the country's legitimating is very significant and that makes it gets the special supports from the government. This is because, in the history of Thailand civilization, it had been dominated by Buddhism starting from the beginning. The history also remarked that all the Thailand kings are Buddhists since then till now. This is also written in Section 9 of the constitution that "The king of Thailand must be Buddhist and fight for Buddhism" (Constitution of Thailand revision 2007:3)

The protection rights given by the government towards the believers do not mean that they should not follow the good moral in practicing their rights to avoid from interrupting the public benefits. The Constitution of Thailand stated that the law protects the rights that related to the religious practices such as the Monks Law Act 1962 (revision 1992), where people are prohibited from slandering or humiliating Buddhism. Violation of the act can bring the doer to the prison which is no more than one year or fine which is not more than RM 2,000. Other than that, the Crime Law Arrangement 1956 (revision 1976) Section 206-208, people are prohibited from disturbing the worshipped house or any religious practices of each religion. The violation of the act can bring the doer to prison for 1-7 years or fine between RM200 - RM1,400.

The Constitution of Thailand (revision 2007) stated that "... will sponsor and protect Buddhism and other religions". Following the statement, in 2010 government had contributed money to support the religious activities for every religion in Thailand worth RM $360,000,000$ to the Office of National Buddhism which acted as the government free organization in handling the religious matters and determine the educational curriculum as well as giving the facilities with various Buddhism service in all areas. While in 2010, government had prepared the budget through Religious Department worth RM $12,500,000$ to the Buddhism organization, RM 3,560,000 to Islamic Organization and RM 300,000 to Christianity, Hindus and Sikhs organization. Apart from that, the Religious Department had also prepared budget worth RM 3,800,000 as the capital for religious research, students' activities and organizing Dharma summer camps, the RM 1,060,000 capital for Religion Development Project in the districts of the Southern of Thailand (The Democratic Office of Human Rights 2011:3).

The budget prepared for the Buddhism and Islamic organizations are including the educational institution development, religious study project whether in private or public schools, daily allowance and transportation budget for the Buddhist monks and religious teachers. The budget is also covering the annual budget for the improvement of religious centres such as temple and mosque. Moreover, the National Buddhism Department has approved the budget worth RM 40,300,000 to improve the temples and Buddhism institutions. In 2009, the Religious Department has prepared budget worth RM 2,000,000 to improve the worshipped houses, religious learning centres other than Buddhism. In brief, the budget had improved 515 mosques and 78 worshipped houses including Christianity and Hindus in all districts of Thailand.

Furthermore, all religions had been given the opportunity to spread their religions openly. It is found that there were 5,609 Buddhist monks were given the task to spread their religion in the state, and they were trying to dominate the areas of Northern of Thailand border (the aborigines) who have not embraced any religions. This is also including the 1,857 Buddhist monks as the international preachers in overseas. While the 1,380 Buddhist monks acted as the religious guidance and advisor in 30 outside countries. There were 317 temples in 27 countries that had been registered under the National Buddhism Department. In addition, in 2009, there were 400 scholars of Buddhism theology had to do Dharma practical in various districts for 4 years. The practical were among the policies in spreading the religion that had been suggested by the National Buddhism Department (The Democratic Office of Human Rights 2011:3-4) Nevertheless, the 
spreading of Islam, Christianity, Hindu and Sikh in Thailand were not sponsored and supported by the government, as the amount of their preachers are smaller compared to the preachers of Buddhism whether inside or outside Thailand.

\subsubsection{Education}

Presently, government has given the approval for religious courses in the private or public schools. In 2003, the Ministry of Education had set a course called "Social, Religion and Cultural Research" in the educational curriculum with the condition that each student must learn the course for about 1-2 hour per week. The course is actually a research about the religions that have existed in Thailand including Buddhism, Islam, Christianity, Hindu and Sikh. Besides, for those who were interested to learn more on religion, they can transfer the credit to public school.

In the meantime, Muslims children had been placed in the kindergarten. The learning hours are after the national primary school hours (standard 1 to 6 ) or every Saturday and Sunday depending on their respective areas, located at the mosque. Moreover, the kindergarten curriculum is under the Religious Department. Conversely, in Satun, Narathiwat, Yala, Pattani and other areas in Senggora, the kindergarten curriculum is controlled by the Ministry of Education.

Nevertheless, for the secondary school level, the Ministry of Education has approved the private school to have the "two systems school" which combined the religious and academic courses as arranged by the government. That type of learning is certified and supported by the government in terms of financial and learning tools. In 2003, government has allowed the private religious school to focus their learning on Islam, but they had to use the religious educational curriculum that has been certified by the government and the Ministry of Education. Hence, the students that graduated from the schools will receive a certificate that has been certified by the government and they can further their studies in university.

In the case of the private religious school or known as "traditional Islamic schools (pondok)" are mostly located at the three districts of the Southern of Thailand, they will be given the financial support from the government based on the teachers teaching in those schools, only if they are registered under the government. In 2004, there were more than 1,000 traditional Islamic schools (pondok) that have been registered under government. Even though the students who have graduated from the traditional Islamic schools (pondok) did not received the certificates that have been certified by the government, they were given the opportunity to sit for the examination that was meant to measure their religious knowledge level in the private religious schools certified by the government. If they passed the examination, they will get the certificate certified by the government and further their studies in higher level.

\subsubsection{Festivals}

Government has announced that the religious festivals are also the public holidays for every believer in Thailand, such as Magha Puja Day (on the $15^{\text {th }}$ day of the $3^{\text {rd }}$ month based on the Qamariah calendar which falls on February), Wesak Puja Day (on the $15^{\text {th }}$ day of the $6^{\text {th }}$ month based on the Qamariah calendar which falls on May) Asalha Puja Day (on the $15^{\text {th }}$ day of the $8^{\text {th }}$ month based on the Qamariah calendar which falls on July) and Vassa day.

Pakorn Prichawuttidaet, the advisory committee of the Southern of Thailand Management and Development Organization said that Yongyut Wichaidit the Deputy Prime Minister and the Minister of Home Affairs had a meeting with the committee of the strategic and development of the Southern of Thailand 4/2011. They have decided that Tru-Chin Day, which is the noble day for the Chinese as the public holiday. Other than that, they have also decided that Eidul-Fitri and Eidul- Adha as the special public holidays for the citizens of the Southern of Thailand (Pattani, Yala, Narathiwat and Satun), in order to maintain the cultural tradition and give the opportunity for every believer to practice their religious ritual happily.

In brief, statements that have been mentioned above are giving the idea that with all the facilities, contribution, and supports by the government to the citizens in handling the problems of the oppression of religious freedom especially among the Muslims, they have acknowledged the Muslims' rights in the Southern of Thailand at one level. Nonetheless, in order to handle the crisis among the believers in the Southern of Thailand, such help and contribution should be carried out continuously. They must also be careful in every action in order to maintain the peaceful life of the community who lives among the different believers that might cause the religious conflict. According to Supab, C. (1974), the main step that should be taken by the government in their effort to overcome the conflict between the believers is the government should use the motivated manpower and identify the background of the religion. For instance, the background of Islam which has the majority believers in the Southern of Thailand that owns its unique characteristics. It is also different from the Buddhist majority in Thailand in terms of religion, race, language, culture, status and custom (Supab, C. 1974: 79). Furthermore, the community especially the government must be responsible and open minded in accepting every 
opinion, as well as be motivated in creating the peace of living religiously. They must also have a special organization that can arrange, manage and protect the religious related rights (Paiterakunpong, P. 2005: 83). This step is also supported by Chankhiri, R. (2007), where he claimed that the main factor that caused the continuous crisis among the believers in the Southern of Thailand since the reign of Rattana Kosin until the regime of Phibun Songkram is the ruling system of the government where they failed to diminish the local Muslim Malays is the Southern of Thailand (Chankhiri, R. 2007: 81). Finally, the forming of peace in community especially in the context of multireligion community, the responsibility is not only under the government, but it is also the responsibility of all believers to be motivated, honest and aware in carrying their role of living in the multireligion community. In order to achieve the objective, each believer should honestly and deeply understand their own religious values. At the same time, they should learn the variety of religion possessed by the community in order to get better self adaptation. If that attitude is instilled in the heart of every believer, it is not impossible to have a community that respect and love each other. They would also be ready in accepting the good things from the different religions.

\section{Conclusion}

A democratic country should implement the policy that can bring truth and justice. If the country failed to bring those elements, it will be regarded as an uncivilized country. From time to time, history has proven that there is a long and continuous controversy among the believers in the Southern of Thailand. With all the effort taken by the government to overcome the issue, it portrays that the Thailand government has been aware and has acknowledged the Muslims rights. This can be proven by the attention given by the government in terms of facilities, supports and financial assistance in every religious and educational matter. Other than that, freedom of religion has been acknowledged in the Constitution of Thailand in Section 37 and others. In addition, all the contributions have changed the status of the Muslim Malays become higher than in the past and their rights have also been acknowledged. In the context of the multireligion community as in Thailand, the implementation of a certain policy should take into consideration every side of the community. The policy that has been implemented wrongly can cause many conflicts. For example, in the aspect of practicing the same custom which has both advantages and disadvantages. In brief, it is very important for the multiracial community who possess the different customs, culture, language, religion and social class in the Southern of Thailand to have the special rules and regulations, as well as laws that can bring peace and harmony to the society.

\section{References}

Achwanichakun, K. \& Vachanasara, K. \& Siangdang, H. (2009). Terrorize and Death under the Government Policy: Study Case in the Southern of Thailand. Bangkok: SC Print.

Alisa, H. (2009). Muslim Identity in Rueso Komunity: Southernmost Province of Thailand. Academic Journal of the Faculty of and Social Science and Humanities, Prince of Songkhla University Pattani Campus.

Chankhiri, R. (2007). Depth of the Conflict Situation in the Southern of Thailand. Bangkok: Suwanphum Apiwat.

Dassaey, P. (1984). Problem of the Minorities in the Thailand: Unity and Communist. Bangkok: Thammasat University.

Duangpattra, S. (1977). Minorities in the Thailand: Study Case of Community against Provinces in the Southern of Thailand. Bangkok: Thammasat University.

Dailynews. (10/01/2012). http://www.dailynews.co.th/education /6908 [17/May/2013].

Faiz, A. (2009). Patani Malay Language Among Malay Student in the Southern of Thailand: Preservation and Elimination. Dissertation Master of the Faculty of Social Sciences and Humanities, National University of Malaysia.

Jidmoud, S. (1988). Identity: Patani Muslim Malay. Bangkok: Sanga Suchira Amphone.

Mamau, A. (2012). http://www.enlightened-jurists.com/page/192 [6/May/2013]).

Paiterakunpong, P. (2005). Cultucal Disagreement Between Islam and Buddhism in the Southern of Thailand. Bangkok: Suwanni Printing.

Pissuwan, S. (1982). Integration of Muslim Malay in Thailand During Rattana Kosin. Bangkok: Institutions of Studies in the Thammasat University.

Pissuwan, S. (1984). Political Violations against Human Right in the Southern of Thailand. Bangkok: Institutions of studies in the Thammasat University.

Suhaimi C. H. (2007). Demonstration of Patani People 1975-1976: Study on Revival Among Patani Muslims in the Southern of Thailand. Dissertation Master of the Institutions of Alam dan Tamadun Melayu, National University of Malaysia.

Supab, C. (1974). Problems in the Southern of Thailand. Bangkok: Taesa Piban 68.

Rangsiyokret, S. (1967). Public Access in the Southern Thailand. Dissertation Master of the Faculty of Social Sciences, Thammasat University.

Wan Kadir C. M. (2002). Muslim Malay in the Southern of Thailand. In Fariz M. Z, Zulkarnain M. \& Samsu A. M (Ed.), Muslim Minorities in Thailand, (p 7-32). Bangi: Penerbit L Minda.

Warner, K. (1998). Islam in the Thailand: Notes on the History of Muslim, Thai Islamic Modernisation and Separatist Movement in the Southern of Thailand. In Fariz M. Z., Zulkarnain M. \& Samsu A. M. (Ed.), Muslim Minorities in Thailand, (p 33-60). Bangi: Penerbit L Minda. 